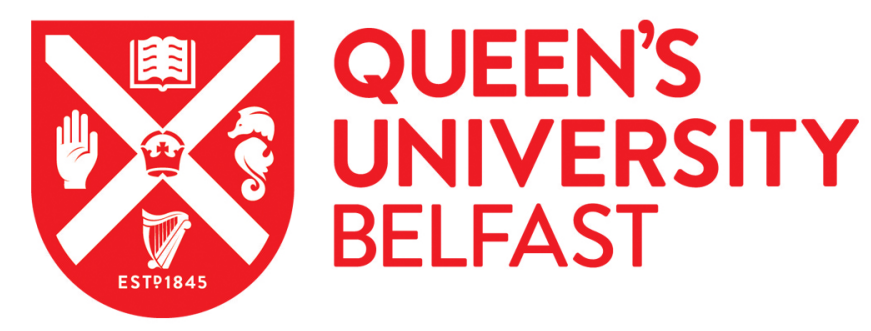

\title{
"The European Parliament projecting cultural diversity across Europe": European Quality Films and the Lux Prize
}

Baschiera, S., \& Di Chiara, F. (2018). "The European Parliament projecting cultural diversity across Europe": European Quality Films and the Lux Prize. Studies in European Cinema, 15(2-3), 235-254. https://doi.org/10.1080/17411548.2018.1442619

Published in:

Studies in European Cinema

Document Version:

Peer reviewed version

Queen's University Belfast - Research Portal:

Link to publication record in Queen's University Belfast Research Portal

Publisher rights

Copyright 2018 Intellect. This work is made available online in accordance with the publisher's policies. Please refer to any applicable terms of use of the publisher.

\section{General rights}

Copyright for the publications made accessible via the Queen's University Belfast Research Portal is retained by the author(s) and / or other copyright owners and it is a condition of accessing these publications that users recognise and abide by the legal requirements associated with these rights.

Take down policy

The Research Portal is Queen's institutional repository that provides access to Queen's research output. Every effort has been made to ensure that content in the Research Portal does not infringe any person's rights, or applicable UK laws. If you discover content in the Research Portal that you believe breaches copyright or violates any law, please contact openaccess@qub.ac.uk. 
"The European Parliament projecting cultural diversity across Europe": European Quality Films and the Lux Prize.

\section{Stefano Baschiera and Francesco Di Chiara ${ }^{1}$}

The quest for a shared definition and understanding of the notion of "European cinema" can be traced in the activities of several supranational institutions and programmes, from Creative Europe to Eurimages. It emerges in their policies, in the selection of awarded films, in the series of commissioned studies and reports, in the funding guidelines, in the press releases and marketing activities.

For instance, by engaging with co-production agreements and exhibition networks, the relevant supranational policies and regulations depict an institutional vision for European cinema, a set of ambitions about quality and artistic merit, and a will of differentiation with respect to the alwaysthreatening Hollywood counterpart.

Among these supranational initiatives, we argue that the Lux Prize deserves particular attention for its being directly linked with the European Parliament and for its focus on distribution rather than on production. Instead of shaping through funding the making of a European cinema, it looks at the existing production in the $28 \mathrm{EU}$ member nations in order to select the film that more deserves to be seen across the continent, thus allowing us to consider through their choices what kind of cinema is best representative of the Union.

The Lux Prize was created in 2007 by the European Parliament in an effort to build "a stronger European identity" through the cinema. According to their website, it aims to do so by selecting and giving visibility to films showcasing a variety of approaches to social and political issues that are at the centre of European public debates, helping to "celebrate the universal reach of European values, illustrate the diversity of European traditions and shed light on the process of European integration".

The prize ultimately aims to become a "quality label backing European film production" and help the distribution and availability of the films selected, overcoming the fragmentation of the European market. As it often happens with state or international forms of support, here the term "quality" is not explicitly defined, but rather relies on implicit assumptions (King 2016, 360). The Lux Prize intends the term as a synonym for "art cinema", understood as an institution operating as a niche

\footnotetext{
${ }^{1}$ This work is the fruit of genuine and intensive collaboration on all parts and aspects of the essay. Each of us was principally responsible for writing almost exactly half of the essay, as follows: Stefano Baschiera wrote the Introduction, 'Mapping Europe: territories and the Lux Prize film selection', 'Main Goals II: Distribution', 'Ida, Mustang and Toni Erdmann' and the Conclusions, Francesco Di Chiara wrote 'The Lux Prize as a Film Festival: Questions of Prestige and Symbolic Power' The Lux Prize as an “Anyplace" or as a 'Nowhere" Film Festival?' and 'Main Goals I: European Values'.
} 
sector within the broader realm of the cinema (Neale 1981, 27) and defined by modes of production, modes of consumption and, most importantly, textual features which are at odd with that of mainstream (especially Hollywood) film production. Art films have always taken as a "moral prerogative the representation of the underrepresented [and] embrace the socially excluded, including working-class subjects [...], national subjects [...] and sexual minorities" (Galt and Schoonover 2010, 15). However, it is noteworthy that, throughout the past twenty years, this tendency towards the representation of social issues has intensified in European cinema in parallel with the growing importance of European supranational support schemes, moving beyond national specificities. Therefore, it is not surprising that the Lux Prize explicitly links said themes to its "quality brand".

The selection process of the prize is a matter of interest in itself as it involves, over a 5-month period, institutional spaces, events, industry figures, cultural representatives, policy makers (from Eurimages and Creative Europe) and, finally, members of the EU Parliament. A 21-person panel is approved each year by the European Parliament's Committee on Culture and Education which introduces 7 new members. The panel meets in June in Brussels to select the 10 finalist films, which are announced in July at the Karlovy Vary International Film Festival. A further selection of 3 films ultimately compete for the Lux Film Prize and, after being presented at the Venice Film Festival, they receive a translation in the 24 official European Languages and a distribution to the 28 member states during the "Lux Film Days".

The winner of the prize is ultimately voted by the European Parliament and announced in Strasburg in September. It then receives further promotion and distribution support.

Some central elements emerge clearly even from this brief overview of the prize: its supranational and political nature; the link between cinema of quality and social representation; the ideal role played by cinema to frame EU identity and EU values; the educational scope of the prize; the link with the festival circuit; the problematic question of cross-border distribution and availability of EU productions.

These questions can be summarised according to three areas of enquiry, each requiring a different methodological approach.

The first concerns the question of quality and the exception culturelle as fundamental elements to define European cinema. To engage with this aspect, in this article we will look at the Lux Prize through the lens of Bourdieu's concept of cultural capital as understood in the context of film festival studies. This approach will also allow us to reflect on the links between the prize and the festival circuit. The Lux Prize as "quality label" shall therefore be considered within the theoretical 
framework of the creation of a cultural capital for the film, in a way not dissimilar from the process of selection/award/marketing of an established film festival.

The second area of interest regards the problematic definition of European values (Toggenburg 2003; European Union Agency for Fundamental Rights 2013) as understood, in this case, by the European Parliament. Against the backdrop of studies in political science, our investigation intends to tackle issues of European identity and values as they emerge in the films selected. We argue that, by promoting a certain kind of film engaging with political and social public debates, the Lux Prize engages in a discursive process aimed at constructing a collective identity and legitimising its institutions, through a communication about the policies of the EU Parliament and the pertinence of its agenda about a common set of values (Schmidt 2011). The educational kits provided by the Lux organisation for the finalist films will be taken into account in order to analyse the terminology and the description of the public debates on the basis of its idea of Europe.

Finally, the third question emerging from the Lux Prize regards its main outcome, i.e. the distribution and availability of the winning films to the $28 \mathrm{EU}$ member states.

The Lux Prize directly recognises the importance to tackle the question of distribution as the “Achilles' heel" of the European Film Industry (Lux Prize website), addressing in this way concerns raised by several recent studies and reports about the fragmented nature of the film market in Europe (see for instance Katsarova 2014; Bondebjerg, Novrup Redvall and Higson 2015). The increase over the years of the presence of distributors in its selection panel and the introduction in 2012 of the Lux Film Days are another sign of the centrality of distribution to the Lux Prize. We maintain that the Lux Prize implicitly manifests the shortcomings of supranational policies addressing issues of distribution and those related to the cross-borders availability of films and to linguistic fragmentation. We will address these issues with reference to production policies and via a film industry studies framework.

By bringing together these three areas of enquiry in the analysis of the Lux Prize we ultimately want to consider it as an exemplary case of self-representation of supranational politics and institutions, in their attempt to define what a European identity actually "needs" to be, and what its quality cinema is supposed to look like. 


\section{The Lux Prize as a Film Festival: Questions of Prestige and Symbolic Power.}

The inception of the Lux Prize in 2007 can be seen as part of a general trend of prize proliferation that has progressively affected the cultural scene since the early $20^{\text {th }}$ Century (English 2008). In fact, at the time of its introduction, the Lux Prize joined a film awards scene already crowded with an ever-growing number of international film festivals and with several national film awards, such as the Goya Awards, the David di Donatello, and the Deutsche Filmpreis, as well as with prizes bestowed by supranational entities, as is the case of the European Film Awards and the Nordic Council Film Prize. The Lux Prize shares some basic objectives with some of the aforementioned awards - that is, to celebrate European cinema, to add symbolic value to European film production, and to help differentiating the European products from Hollywood. However, at the same time the Lux Prize arguably occupies a peculiar place in the film awards scenario. First of all, it is a prize created by a supranational institution with an explicit political agenda and, consequently, it is meant to be awarded to films which are representative not only of the cultural output of European cinema, but also of European shared values. As it is explicitly stated in the Lux Prize website, this award has been conceived as an "innovative way to explore major European policy areas such as immigration, integration, poverty and violence against women". Therefore, the idea of "quality", which underlies the competition, is apparently related not to the logic of "art for art sake", normally associated with the cultural policies of film festivals, but rather to the interpretation of the European values promoted by the European Parliament. In particular, this idea of quality is related to how films are able to engage with specific politics and/or areas of intervention which are pertinent to the work of several EU Parliament Committees focusing on social and human rights issues, which again are explicitly listed in the Lux Prize website.

Secondly, the Lux Prize can also be considered to be part of what Marijke De Valck (2007) has described as a transnational film festival network. The timeline of the Lux Prize's selection process runs parallel to, and is closely integrated with, that of the European film festival circuit. Every year a new Selection Panel is formed in February, after the Berlin Film Festival. Then, in June, shortly after the Cannes Film Festival, ten competing films are selected and then announced in July at the Karlovy Vary Film Festival. Finally, the three prize finalists are revealed in September, at the Venice Film Festival, while the final vote is held at the European Parliament in Brussels in November. This close relationship between the Lux Prize and the European film festivals circuit also extends to the composition of the Selection panel. This board, again according to the Lux Prize website, is highly heterogeneous and "includes producers, distributors, cinema operators, festival directors and film critics, representative of the European Commission (Creative Europe) and of Eurimages". However, since 2012, the Panel members who have in their curriculum a past 
experience as festival director or festival programmers have consistently increased, settling above a $40 \%$ share, with a peak of more than $60 \%$ in the 2016 edition. The composition of the panel and the background of its members have a major role in the shaping of the Lux Prize competition. Although the Members of the European Parliament award the final prize, the Selection panel is responsible for the complicated pre-selection mechanism as well as for the choice of the three finalists. Therefore, it can be argued that they fulfil a role similar to that of a film festival curator.

Film festival studies methods and concepts allow us to examine the role played by the Lux Prize in relation to functions commonly associated with film festivals - that is, gatekeeping, transfer of symbolic capital, tastemaking, etc. - and how said functions interact with the values, with the political agenda and with the idea of "quality cinema" expressed by this award and its sponsoring institution.

Film festivals have recently become one of the most relevant fields of investigation in the film studies sector. Among the several approaches to this area, we want to highlight two that are particularly suitable to deal with the peculiarities of the Lux Prize. The first concerns an application to film festivals of the concept of "capital", first developed in the 1980s by Pierre Bourdieau (De Valck 2007, 2016). The second is related to the spatial dimension of film festivals, and the role these ventures play inside nation-building processes, in the touristic promotion of local areas, or in the establishment of transnational film cultures (see: Elsaesser 2005; Czach 2004; Iordanova 2011). In a recent book chapter dedicated to the role of film festivals in the creation and distribution of cultural value, Marijke De Valck (2016) engages with three major concepts elaborated by Pierre Bourdieau in the 1980s - field, capital and habitus - in order to consider the role played by the film festivals network in respect of contemporary film culture. We argue that the concept of "capital" is very helpful to analyse the Lux Prize and its activities. It refers to the different kinds of capital (apart from the sheer "economic" capital) that, according to Bourdieau, are exchanged between social agents. In fact, rather than simply earning money, the different subjects involved in prizes and film festivals are more likely to acquire social capital (that is, access to resources granted by one's network of connections), cultural capital (referring to a person's status in society) and/or symbolic capital (the access to resources that is granted by someone's prestige and recognition). In this respect, prizes and festivals are the "most effective institutional agents of capital intraconversion" (English 2008, 159), that is the transformation from one kind of capital to another, as they constitute an institutional network where transactions between cultural, symbolic and economic capital are negotiated. This is a pivotal point in the film festival studies literature, and De Valck offers a general model where the canonization procedures of festival programmers result in a value-adding process. Films can benefit inside of their value chain regardless of whether the festival 
selection - or even an award - will eventually translate into a wide distribution in the mainstream circuit. However, in the case of the Lux Prize, the creation, the circulation and the transaction of these multiple kinds of capital are quite complex. The first issue concerning the relationship between the Lux Prize and the circulation and conversion of capital is the process of value adding. After the debut in a particular film festival, a film is usually further screened and/or selected for competition at other festivals and/or awards, and this continuous exposition results in a progressive value-adding process. The most visible outcome is the proliferation of prize logos on the poster of a festival film, which has been picked for theatrical distribution. In other words, by being selected and participating in festivals and special events, a European film (especially if belonging to the art cinema sector) builds a reputation (a symbolic capital) that will eventually affect its chances on the market, allowing for a conversion of the symbolic capital into economic capital. From this perspective, to assess the role of Lux Prize in the value-adding process of a film is tricky. In fact, despite being bestowed by an important political institution, the Lux Prize alone is hardly able to affect the prestige of the finalists or even of the winner. Firstly, the Lux Prize is far from being well known, and it is seldom advertised outside the channels of the European Parliament itself. Secondly, the political dimension of the Lux Prize could compromise the value-adding process inherent to the award, as the political agenda of the institution offering the prize can be perceived to be at odds with the aesthetic values normally associated with film art (Czach 2004, 84; Jäckel 2015). Although the Lux Prize alone has probably little power to increase the prestige of the selected films, it works in synergy with other prizes and festivals to the creation of a canon of contemporary European cinema and to the value-adding process of a few selected works. The films selected for competition have already, in most cases, premiered at a festival, and the selection for the Lux Prize helps them consolidating their prestige. This is particularly important when it is not an established author who directs the film. While the first two editions awarded transnational stardirectors such as Fatih Akin and the Dardenne brothers - for Auf der anderen Seite (The Edge of Heaven, 2007) and Le silence de Lorna (Lorna's Silence, 2008), respectively - in the following years the selecting panel has generally favoured the works of less prestigious names ${ }^{2}$. Moreover, it has to be noted that, from the 2009 edition, the selection panel has avoided including in the finalist roster films that had already won a major prize at one of the three big European festivals (Cannes, Venice and Berlin) ${ }^{3}$ - a choice that is coherent with a value-adding strategy conducted towards emergent filmmakers.

\footnotetext{
${ }^{2}$ A notable exception is French director Robert Guédiguian, who won the Lux Prize in 2011 with Les neiges du Kilimandjaro (The Snows of Kilimanjaro).

${ }^{3}$ The only, notable exception is Just the Wind (Csak a szél, Bence Fliegauf, 2012), which was selected as a finalist after having already won a Silver Bear at Berlin.
} 
Therefore, the Lux Prize intersects with the logics of gatekeeping and of the creation and distribution of symbolic power, which are both operating in the context of the film festival circuit, eventually playing a role, along with other awards, in the consolidation of the canon of contemporary European quality cinema. Nevertheless, this transfer of symbolic power should also work the other way around: the symbolic power generated by the Lux Prize is meant to augment the prestige of the European values (and, conversely, European institutions) that these films are meant to represent.

\section{The Lux Prize as an "Anyplace" or as a "Nowhere" Film Festival?}

The spatial dimension is the other major strand of the film festival studies approach that we are going to take into account in our analysis of the Lux Prize. As Elsaesser (2005, 84-88) points out, "film festivals [...] make up a network with nodes and nerve endings" where "the locations themselves have to be read symptomatically in relation to the history, politics and ideology, that is in their typically European context of temporal layers and geographical sedimentations". In this perspective, the creation of major European film festivals in the $20^{\text {th }}$ century was aimed at gaining national prestige. At the same time, festival locations not only retain a role in the geopolitical agenda of their hosting nation, but are also chosen according to the needs of the tourism industries. The Cannes and Venice film festivals, for instance, take place in seaside resorts, before the start or after the end of the touristic season, while the Karlovy Vary Film Festival takes place in a city renowned for its thermal spas. Starting with the 1980s, the film festival circuit has started to include also smaller, peripheral centres. Towards the early 2000s, the spreading of a new class of young and wealthy professionals seeking culture-rich environments produced phenomena of culture clustering, causing the rise of cultural events such as film festivals located in city neighbourhoods or smaller local areas (Elsaesser 2005, 85-86). As English (2008, 2772) argues, "the rise of film festivals has as much to do with the spread of 'place promotion' in its contemporary form - a blending of modern marketing practices into urban planning and public policy - as it does with the proliferation of prizes and awards".

In this respect, the Lux Prize occupies a fascinating position. On the one hand, this award has been conceived by a supranational institution (the European Parliament) as a means of increasing the prestige of the European Union and of spreading the awareness of its values among the citizens of 
the EU. Therefore, the first meeting of the selection panel and the final vote take place in the two branches of the European Parliament - in Brussels and Strasbourg respectively. However, the Lux Prize also organizes the screening of the three finalists across the European Union, including in countries where they have not been picked for theatrical distribution. Therefore, from a spatial point of view, the Lux Prize transcends the national dimension associated with film festivals, as it is meant to celebrate the values of the supranational project of the European Union. At the same time, though, this award also transcends the local level of smaller festivals, as it is not located in a particular area or neighbourhood, but in more than 50 locations at the same time. From this point of view, the Lux Prize mirrors a tendency of contemporary film and awards that has been highlighted again by English $(2008,2759)$, when he states that the "recent frenzy of prices and awards has begun to foster not merely a denationalization but a more radical deterritorialization of prestige, an uncoupling of cultural prizes [...] from particular cities, nations, even clearly defined regions." The peculiar spatial configuration of the Lux Prize can be put in relation with this "rapid proliferation of migratory, virtual, unhomed, or seemingly 'anyplace' film festivals [...] radically disengaged from the project of urban place-promotion" (2822). Through the introduction of the Lux Film Days, the Lux Prize has arguably become some sort of an "anyplace" and "anytime" film festival. The complicated spatial configuration and schedule of this prize are in fact related to the complex configuration of the European Union, which is articulated in 28 member states and in a multitude of smaller regions whose cultural diversity has to be protected and valorised, and where the theme of the transfer of sovereignty between the EU and member states is still harshly debated. Therefore, instead of being concentrated in a particular location, or of offering premiers in major European cities, the screenings of the Lux Prize film days are widely dispersed on the European territory. Moreover, the screenings are not synchronized between the various countries/locations, but are scattered along a very long window, which goes from September to January - even though further screenings of the three finalists after the Lux Prize has been awarded are not uncommon. In fact, the number of theatres offering the free screenings is uneven from nation to nation, and the frequency of the Lux Film Days screenings is also uneven, as they are organised on a national basis through individual arrangements between the European Parliament and local theatres, which normally belong either to the film festivals or to the art-house circuits.

In principle, this peculiar spatial and temporal configuration is perfectly in line with the Lux Prize's intention to aid the diffusion of European quality cinema and its values throughout the territory of the European Union, thus giving the three finalists several opportunities to find a dedicated audience and improve their chances to be picked up for regular distribution. In practice, however, 
we argue that such a desultory screening system risks to alienate the cinemagoers and to give the perception of the Lux Prize as an unnecessarily complicated venture designed by Euroburocrats. As an "anytime, anywhere" film festival, the Lux Prize risks to be perceived as an award, which does not take place in a specific place and a precise time, even though the screening formula in some respects mimics that of major film festivals.

The expanded accessibility of the Lux Prize films, furthermore, may actually be at the expense of the perceived value of the Lux Film Days: such stretched window prevents the screenings to be perceived as an event, which of course is an essential prerequisite for the success of a film festival or similar kinds of award. In a similar fashion, the connections that the Lux Prize entertains with major European film festivals risks preventing the prize from acquiring its own identity. The most important of such connections is probably the 28 Times Cinema initiative, which takes place at the Venice Film Festival. There, 28 young people selected through the Europa Cinemas film theatres network are representing each a Member State of the European Union and engage in debates and workshops about European cinema along with film professionals or members of the European Parliament. However interesting, this initiative risks to be perceived as one of the many other happenings taking place into its hosting film festival, without imposing its own distinct identity as part of the Lux Prize.

\section{Mapping Europe: territories and the Lux Prize film selection.}

In the intention of the Lux Prize, the three finalist films need to offer a cogent image of European values and the debates that characterise and dominate the public opinion, taking into account the importance of diversity and cultural exception. Therefore, by looking at the 30 films which have reached the final stage over the past decade we should be able to infer not only the European Parliament's ideal portrayal of a cinema that is representative of its policies, politics, and values, but also a geographical and territorial understanding of Europe itself. The Lux Prize selection should hence offer a mapping of Europe both in the story told by the films and through their production background.

Such mapping, however, presents tensions between regional identities, issues and settings, and a supranational attempt to grasp and understand shared values. In doing so, it indirectly reveals how "[n]ew and diverse practices and modes of mobility, migration, and border-control have continually reconfigured the 'new Europe' of the post-Cold War era" (Bayraktar 2016, 3) and the centrality of it in the understanding of Europe. The European expansion after the fall of the Berlin wall led in fact 
to a "growing ethnic, cultural and religion diversity", the creation of a borderless centre promoting movement of people, resources and collaborations, and, at the same time, the establishment of a "common external border, generating a new border regime characterized by the securitization and criminalization of migration" (Bayraktar 2016, 3).

Therefore, supranational screen policies and their attempts to identify and establish common European values within their understanding of "quality cinema", led to an ideal of unity not only by focusing on overarching thematic features able to go past national differences, but also by addressing the question of the European eastward expansion and, in particular, the problematic presence of the external border and shifting forms of migration and deterritorialization.

The prominent authorship role achieved by European directors with a migratory background (Ismaël Ferroukhi, Fatih Akin, Abdellatif Kechice, Tony Gatlif, Ayse Polat etc.) further challenges the notion of national cinema within European art-house (Bayraktar 2016, 7) while, at the same time, is bringing questions of diaspora and transnational mobility at the centre of cultural debates in the EU. Moreover, the production of their work mirrors such questions, underlining collaboration and cross-cultural encounters not within the borderless Europe but across the common external border.

Therefore, the promotion of such collaborations by European screen policies is not aimed at the possible exploitation of new markets or the external promotion of shared values. It is a focus on the periphery in order to define the centre, an attention on the common border to foster the idea of a borderless, diversified, and unified Europe.

Unsurprisingly, the overall trend dominating both the settings and the themes of the majority of films shortlisted by Lux prize is characterised by the idea of the margins, in a tension between regional issues and cross-border identities. The storylines present a plethora of characters living at the margins of society, who are displaced and relocated in search of jobs, roots or belonging.

The films portray a diversified, expanded Europe with a variety of countries (and languages) represented, including Bulgaria, Greece, Slovenia, Hungary, and the Czech Republic, among others. More interestingly, films set in the economic, political, and financial centres of the Union (France, Belgium, Germany) engage with the common border, telling stories of struggle, migration, problematic integration and quests for legality. Finalists like The Edge of Heaven, Illegal (Olivier Masset-Depasse Illégal, 2010) Lorna, When We Leave (Feo Aladag, Die fremde, 2010), and Io sono Li (Andrea Segre, Shun Li and the Poet, 2012), among others, deal directly with migration and look beyond the edges of the European Union, while films like Welcome (Philippe Lioret, 2009) and Mediterranea (Jonas Carpignano, 2015) represent the European boundaries and the persistence of internal borders for non-European, dislocated characters struggling to travel across them 
Finally, other finalists as Just the Wind (Csak a szél, Benedek Fliegauf, 2012), which deals with the slaughtering of Romany families in contemporary Hungary, also portray forms of marginalization internal to the EU borders.

The Europe emerging from the Lux Prize finalists is not a well-established and solid entity, but a place in constant becoming, still adjusting and reflecting on ideas of nation and citizenship.

The borders are always problematized by the characters' travels and by the inclusion of settings in Turkey, Tunisia, Libya, Mozambique as well as languages such as Tunisian Arabic, Russian and Kurdish and characters from Belarus, Iraq, China.

From a production perspective the national belonging of the finalists mirrors the Prize's objective of promoting cultural exceptions and the diversified composition of its panel. While the majority of countries have found representation, the significant presence of co-productions stresses the prize ambition to valorise transnational collaborations and emphasise cross-border shared values.

Particularly interesting is the presence of co-productions with partners beyond the EU, featuring for instance Eurimages countries, in a list that includes Turkey, Brazil and Switzerland.

While the numerous collaborations with Turkey embody the engagement with the themes of migration and cultural relationships at the EU borders, the films' mode of production represents at the industrial level the same tension between regional, national and supranational entities which can also be found in the films' plotlines. As we will analyse when looking at the case studies, regional funding, state aids, and supranational supports work together to support the production of several finalists, framing in this way local and national specificities in a transnational framework and representing the background of public support for the cultural exception of European cinema.

Nevertheless, arguably the question of marginality emerges in the industrial context too, as the majority of finalist films are productions with artistic ambitions but also with low budgets, and that do not easily appeal to wider film audiences. We maintain that the focus on the margins and marginal characters emerging in the themes of the majority of the films shortlisted by the Lux Prize reflects, to some extent, the "becoming-minor" of the contemporary European art film as conceptualized by Laura Rascaroli on the backdrop of Gilles Deleuze and Felix Guattari's critical thought. She argues that the post 2008 recession has underlined the marginalization of Europe on the world stage and raised doubts on the sustainability of the openness and cosmopolitanism of its art cinema, compromising the conditions which supported its expansion as "a major cultural, artistic and economic enterprise" (Rascaroli 2013, 324). As a result, European art cinema began to reflect on its downscaling and its survival in the contemporary global market by deconstructing the "high- 
art" language of its tradition in order to "express an ideological critique of the capitalist society that produced that tradition" (325).

In a process of deterritorialization and reterritorialization of a major language, the "becomingminor" of several Lux Prize finalists is manifested in their political commentary about the sustainability of the European society in times of economic and cultural crisis and in their role as new artistic and marginal practices in the contemporary production landscape.

\section{Main Goals I: European Values.}

After considering the functioning of the Lux Prize, its relationship with the dynamic of transfer of symbolic power and its spatial dimension, in this and the following section we will engage with the two main goals of this prize: the spreading of European values and the cross-border circulation of European films.

The Lux Prize website does not offer a thorough explanation of what the organizers mean with the term "European values". However, in the "Why and what" section, the site links such values with "the diversity of European traditions" and "the process of European integration". The section labelled "European Parliament and Lux" further establishes a clear connection between European identity and a series of "key issues" which are being dealt with by the Parliament and its Commissions: namely, "immigration, integration, poverty and freedom of expression and thought". Before taking into account how the Lux Prize contributes to these European policies, we believe it is necessary to explore the concept of European values and the relationship it entertains with the broader issue of the legitimacy of EU institutions such as the European Parliament. A member of the European Union Agency for Fundamental Rights (FRA), Gabriel Toggenburg has offered back in 2003 a concise survey of the different meanings associated with the expression "European values", and of the institutions that are meant to enforce them. Toggenburg (11-16) distinguishes between three meanings of the term. The first is represented by the "foundational values", invoked already in 1956 and comprising the three pillars of Europe: the establishment of a "political area of freedom and international peace", the creation of welfare in a market economy and, finally, Europe as a project with an "ever higher degree of integration". The second group is represented by the much more hazy - from a legal perspective - yet undeniably important - from a pragmatic point of view - "European ideas", which most European citizens should arguably share. These ideas include, for instance, the triple legacy of ancient Greek culture, of the Roman legal system and of Christianity. Furthermore, they also encompass the ideals of the Enlightenment and, most interestingly, the "remembrance and rejection of Shoah, fascism and Nazism as lieux de memoire of 
European integration". Finally, the third and last group is represented by the common legal principles. These are, from a legislative perspective, the most relevant group, as they have a legal foundation in the Charter of Fundamental Rights in the European Union and in the Treaties. In this respect, the article 2 of the Treaty of the European Union (2012) states that "the Union is founded on the values of respect for human dignity, freedom, democracy, equality, the rule of law and respect for human rights, including the rights of persons belonging to minorities". As pointed out in a recent document issued by the European Union Agency for Fundamental Rights (2013, 9), while some fundamental rights are imposed and guaranteed by the EU, others refer instead to national laws and practices. This is the case with the social rights and, in particular, with the Title IV on Solidarity of the Charter of Fundamental Rights, which includes core rights such as the protection in the event of unjustified dismissal, social security and social assistance, or healthcare and access to services of general economic interest. Therefore, although these rights are recognised by the EU institutions, "the way in which social rights are integrated in the EU Charter of Fundamental Rights reflects the existing diversity with regard to the status of social rights at national level. Consequently, their implementation will not always offer the same degree of protection as other rights" (10).

We maintain that the most relevant topic of this brief survey resides in the fact that there are different kinds of European values. Some of them are non-negotiable - e.g. the foundational values - while others are not legally binding but are supposedly shared by the majority of European citizens, as is the case with the European ideas. Finally, there is a last group of rights that, although being guaranteed by the treaties, may be subjected to different interpretations on the part of national law, because "EU Member States differ in their legal handling of social rights" (9). We would argue that correctly identifying the different values it aims to protect and spread, would help us to better understand the scope of the Lux Prize and of its backing institution. First, this award intends to "celebrate the universal reach of European values, illustrate the diversity of European traditions and shed light on the process of European integration". That is, the purpose of the Lux Prize is to spread the knowledge of fundamental rights and foundational values among the European citizens, in order to build "a stronger European identity". Second, this prize aims at exploring "major European policy areas such as immigration, integration, poverty and violence against women", some of which, as we have seen, refer to values that are interpreted in a different manner through various national contexts and, thus, need a unifying perspective. In other words, through the selected films and the way they engage with the aforementioned issues, the Lux Prize is arguably contributing to frame such values in a wider narrative about Europe, its borders, and the problems shared by its member states. Moreover, the Lux Prize also provides the audience with a narrative about the role 
of their governance, which is "one of the narratives around which a collective identity of the Europeans might be built" (Eder 2011, 40).

According to Vivien Schmidt $(2011,16)$, the emergence of a collective identity and the legitimacy of its institutions are closely connected themes, which are part of a discursive process where communication about Europe on the part of political elites is a vital element in the establishment of a sense of belonging and active engagement on the part of the citizens. In fact, with a simple yet effective formula, Schmidt (19) defines identity as a political construction, which involves not just a sense of being (for instance: shared beliefs) on the part of the general public, but also a doing (an active engagement of both citizens and political elites) and, finally, a saying: a communication, not only top-down but also bottom-up, about shared beliefs and policies. In this respect, one of the main goals of the Lux Prize is to construct a discourse about what European values mean, and what EU institutions are doing in order to protect and enforce them. We argue, though, that very little of this communication is indeed bidirectional, with perhaps the most notable exception of the aforementioned 28 Times Cinema initiative. Most of the discourses related to the prize and to the activity of the European Parliament have instead been conveyed through top-down interactions, for instance through the catalogues and the pedagogical kits.

Made available online as a PDF file downloadable from the Lux Prize website, the yearly updated retrospective catalogue resembles any ordinary film festival catalogue. It offers a brief presentation of each selected film through the award's ten-year-long history, and features production stills, cast and credits information, a brief synopsis and a commentary. However, an interesting piece of information is also added to these profiles. Displayed below the cast and credits, a series of acronyms informs the reader on which Committees of the European Parliament are actively working on the social and cultural issues arising from each selected film. For instance, Pina, the portrait of the celebrated German choreographer directed by Wim Wenders in 2011, is put in relation with the activities of the Culture and Education Committee, while the 2009 winner Welcome, a drama engaging with the themes of migration and cross-cultural communication, is instead considered pertinent to the work of five Committees: Foreign Affairs; Human Rights; Employment and Social Affairs; Culture and Education, Civil Liberties, Justice and Home Affairs. Therefore, following the model elaborated by Schmidt, we can observe that, by providing this information, the European Parliament communicates (through a form of saying) about its own activities (its doing) to an audience composed of European citizens, in the hope they develop a shared sense of belonging (in other words: a sense of being) and of the legitimacy of the institutions that are working to overcome the Union's problems. In this respect, the catalogue complements and 
makes visible the discursive building of a collective identity through a narrative on its governance, which underscores the project of the Lux Prize.

The pedagogical kits are the second medium through which the European Parliament communicates its interpretation of the European values engaged with by the selected films. Commissioned by the European Parliament to Belgian art-house cinema turned small distributor Les Grignoux, and translated in all the 24 languages of the European Union, these pedagogical kits accompany the three finalists selected for the Lux Film Days since the seventh edition of the Lux Prize. The kits can be downloaded from a repository located on the European Parliament website and apparently have no target audience, as it is not made clear if they are meant to be used in schools, or if they are simply aimed at a general audience. Regardless of the intended usage, these publications are as close as possible to being an official guide to how, according to the European Parliament, the selected films should be interpreted by the audience. Therefore, we believe that these documents offer an interesting insight into the particular issues addressed by the films of the last four editions and the relative European values that they represent. Therefore, we have performed a content analysis of the pedagogical kits of the last twelve finalists ${ }^{4}$, in order to extract the recurring keywords emerging from the communication about the selected films. Such analysis has been performed using "Simple Concordance Program 4.09": after having uploaded the content of the twelve pedagogical kit into the software, we have selected the words longer than two letters, which were recurring at least ten times throughout all of the documents. Then we have excluded nouns of places and characters, pronouns and most adverbs. What remained were about thirty keywords, we have analysed in the context of the sentence they were appearing in, sorted alphabetically from "against" to "young". Unsurprisingly, the issues that emerged are related to the third group of European values, the "common legal principles". For instance, only Ida deals with shared "European ideas", such as the common European memory and the rejection of the Shoah as well of the Socialist regimes experienced by Central and Eastern European countries. On the contrary, the reading of the remaining eleven films focuses on rights and principles that are being dealt differently by each member state. For instance, the pedagogical kit about Miele, a film centred on the moral implications of euthanasia, focuses on the different legal status of this practice in several European countries. Most interestingly, this same topic, albeit present also in The Broken Circle Breakdown, is not even mentioned in the film's pedagogical kit, probably because it is set in

\footnotetext{
${ }^{4}$ The twelve finalists for the editions from 2013 to 2016 were the following. 2013: Miele (Valeria Golino), The Broken Circle Breakdown (Felix van Groeningen), The Selfish Giant (Clio Barnard); 2014: Bande de Filles (Céline Sciamma , Girlhood), Ida (Pawel Pawlikowski), Razredni Sovražnik (Class Enemy, Rok Biček); 2015: Mediterranea, Urok (Kristina Grozeva, Petar Valchanov, The Lesson), Mustang (Deniz Gamze Ergüven); 2016: A peine j'ouvre les yeux (Leyla Bouzid, As I Open My Eyes), Ma vie de Courgette (Claude Barras My Life as a Courgette), Toni Erdmann (Maren Ade).
} 
Belgium, where euthanasia is legal. In most cases, a particular theme arises from only one of the selected films. Despite being an extremely urgent issue in contemporary Europe, and albeit being a theme that was prominently featured by the finalist films, the term "migration" occurs systematically only in the pedagogical kit dedicated to Mediterranea, a documentary about the migration from Africa to Italy. The topic of gender equality seems to be the only transversal theme, recurring in the discussion of most of the selected pictures. Sometimes, this theme is present in the form of a clash between modern and patriarchal societies in countries located at the borders of the European Union, for instance Turkey (Mustang) and Tunisia (As I Open My Eyes). In other cases, it can take the shape of violence against women (explicitly shown in As I Open My Eyes and only suggested in My Life as a Courgette); while in Toni Erdmann gender unbalance is represented through the power struggle between sexes at work. The relative exposure of gender equality compared to the other themes involving the rights of the European citizens is particularly interesting, if we consider that only recently it has become a relevant topic also within the European screen industries policies. In fact, following the conference "Women in today's film industry: gender issues. Can we do better?", held at the Sarajevo Film Festival in 2015, the Eurimages film fund (2016) has developed a strategy for gender equality in the European film industry ${ }^{5}$.

More generally, this analysis highlights how the Lux Prize mainly focuses on divisive social rights, which are still being debated in the member states' public sphere, rather than celebrating European ideas that are supposedly being taken for granted by European audiences. This tendency is also affecting themes and the style of the selected works. In fact, films focusing on the European past rarely make it into the finalist selection, while works celebrating European heritage are conspicuously absent, despite the popularity and the perceived quality of this kind of productions in mainstream cinema. On the contrary, the Lux Prize films mostly engage with conflicts present in the contemporary European cultural space or in that of its surrounding countries, and in order to do that, they resort to a realistic style which is commonly associated with contemporary European art cinema. In this perspective, the Lux Prize's reliance on the stylistic features of art-house cinema is not only part of a tastemaking operation aimed at perpetuating the values of a film heritage. Rather, it is the style of European art cinema that seems to be perceived by European institutions as the most viable for tackling topics that are relevant to the contemporary debate on social rights in Europe. In fact, it is worth noting that this attitude is consistent with the current trend in both

\footnotetext{
${ }^{5}$ It could be pointed out that Eurimages operates under the Council of Europe, which is not a European institution. However, Eurimages is the only pan-European film fund financing the production of European films, and as such perfectly integrates with Creative Europe/MEDIA - which only supports other steps in the film value chain - in shaping the policies of the European audiovisual sector.
} 
national and supranational cultural policies, which sees arts as having an instrumental value in promoting social cohesion and community empowerment (Belfiore and Bennett 2008, 6-9.

\section{Main Goals II: Distribution}

Catalogues and pedagogical kits are the two main tools used by the Lux Prize to communicate the European governance's idea of a shared community based on different sets of values. Consequently, the focus of the pedagogical kits and of the selected films lies mainly in social issues, in the attempt to create a cultural debate on divisive topics and on the role of the European Parliament in establishing a shared framework for a collective identity. However, in order to be effective, this message needs to be spread throughout the European territory, and this leads to the second main goal of the Lux Prize project, that is to tackle what is reportedly the weakest aspect of the industry: film distribution.

The 2014 overview of the European Film Industry by the European Parliament underlines the fragmentation of the European market and production as key issues to be faced for further development, alongside the ever-present challenges embodied by the presence of Hollywood films and majors in the European territory.

While the overall film production in Europe witnessed a constant rise over the past decade, reaching in 2016 the record high number of 1603 feature films produced (including fiction and documentaries), the national box-offices and market shares are consistently dominated by fewer Hollywood productions (69.1\% in 2013). While the EU investment in film production has doubled between 2001 and 2008 (reaching a total of 5.6 billion euro), it has generally lacked ambition and a selective approach. The result is the rising number of films for regional and national audiences and an average budget per film which continues to be significantly lower than Hollywood productions (Katsarova 2014, 4)

The European Parliament and the different observatories monitoring and policing the film industry acknowledge this problem and identify its structural causes, but they struggle to find a solution for it. The fragmented nature of European film production is opposite to the vertical integration of the US majors, as manifested in particular in their control over distribution.

The ever-growing state support to the industry, which has developed across Europe through a number of different schemes and incentives, is very much focused on production, thus contributing to the increase in the number of films that are made, while overlooking questions of availability and cross-border distribution. The same attention to production can be seen in the activities of the supranational support provided by the Eurimages programme, which again leaves important aspects of marketing and distribution at the margins. 
From this perspective, the Lux Prize not only wants to show the active involvement of the European Parliament in the film industry, considered as an important element of the European identity and its values; it also aims to address the question of the cross-border availability of films and of the language barriers by focussing on distribution. In doing so, the prize policy is consistent with other European support schemes such as the Europa Cinemas network, which significantly often provides the European Parliament with venues for the Lux Film Days screenings.

The way in which the Lux Prize aims to heal the Achilles' heel of European cinema is twofold; the first, as previously discussed, is by granting a cultural capital to the films selected and thus by the consequent visibility and appeal to wider markets and different distributors. The Lux Prize ideally works as a "label" of quality to be used in marketing and promotional activities and, as such, it should help the film to find a distributor in different European territories. Moreover, the three films in competition are screened at 18 festivals and, through the Lux Film Days, in more than 40 cities, thus potentially meeting new cross-border audiences and accumulating further cultural capital from their presence in the festival circuit.

Secondly, instead of awarding a direct grant, the Prize provides subtitles in the 24 EU languages for the three films in competition; in addition, the winner receives further support in the form of adaptation for the visually and hearing impaired. This represents a tangible intervention, through which the European Commission offers a strong narrative of its activities and an understandable answer to the distribution problem. The subtitling can in fact be seen to be an achievement per se of the European Commission's backing of film circulation and, at the same time, is a tangible proof of such intervention. Nevertheless, it is difficult to quantify its impact on the cross-border availability of the selected films and their attractiveness to international distributors. The data on admissions of films released in Europe provided by Lumiere confirms that the majority of finalists of the Lux Prize between 2007 and 2016 found widespread distribution across Europe. Nevertheless, 6 films out of 30 failed to find a theatrical distributor in 10 or more countries, with Občan Havel (Citizen Havel, Miroslav Janek and Pavel Koutecký), the 2008 finalist, having only been screened in three nations.

Numbers are undoubtedly better if we focus on the winners of the Lux Prize, which have travelled in at least 15 territories and have had an average admission of 1 million tickets sold in the EU. Nevertheless, with the exception of France, the distribution of the winning films in nations not directly involved in their production does not generate significant admission numbers, showing once again the fragmented regional nature of the European "quality cinema" and, indirectly, underlining some of the shortcomings of the Lux Prize itself. 
Even assuming that the cultural capital generated by the prize, the cross-European visibility offered by the Lux Film Days, and the financial aid given by the subtitling actually work in spreading across Europe the winning films and the "European values" they embody, their role in addressing the structural and industrial issues of distribution in Europe is doubtful.

We would argue that the actions of the Lux Prize to some extent repackage existing forms of marketing of art cinema (the festival circuit, the importance of "education" etc.) offering an institutional, supranational intervention in its promotion, with the clear goal of becoming a quality a label. However, these interventions continue to marginalise European production in the "art" realm and do very little to address the impossible competition with the vertically integrated Hollywood majors as well as to promote new policies to shift the attention of state aid from production to marketing/distribution. In fact, by straightforwardly identifying "quality" with "art cinema" instead of focussing on other possible kinds of more audience-friendly quality films - for instance, middlebrow prestige films which feature mainstream style and narrative coupled with mid-to-high production values - European institutions tend to perpetuate the constitutive problems of the circulation of European cinema.

\section{Ida, Mustang and Toni Erdmann.}

The last three winners of the Lux Prize at the moment of writing, Ida, Mustang and Toni Erdmann, are excellent examples of the cultural capital the award generates and the overall role played by the concept of marginality in the contemporary European art cinema landscape.

The three films are the result of co-production agreements, which received regional, national and supranational support (the latter notably from Eurimages), reached wide international distribution and achieved critical praise. Ida, Mustang, and Toni Erdmann have featured strongly in key film festivals across the globe, received several awards and scored well at the box office, making them examples of successful European art cinema for contemporary standards.

It is noteworthy that, despite their very diverse settings and plotlines, the three winners represent different embodiments of the idea of marginality and of "becoming-minor", focusing on the peripheries and on characters struggling to find their place in the society, while clashing with an incumbent past.

$I d a$ is a co-production involving Poland, Denmark, France, and the UK, made with the support from the city of Lodz, the Danish Film Institute, the Polski Instytut Sztuki Filmowej, and Eurimages. 
In Europe, the film was distributed in 27 nations, collecting a total of 1.445,997 admissions over 3 years (from 2013 to 2014). Moreover, Ida managed to perform well at the US box office, where it was also nominated for two Academy Awards, winning the one for Best Foreign Language Film. The list of festivals where Ida was screened includes Toronto, London, and Warsaw, while it was nominated in seven categories at the 27th European Film Award (winning five awards).

Set in Poland in 1962, the film tells the story of a young, orphaned Christian nun who, on the verge of taking vows, discovers that her parents were Jewish and begins a quest to unveil both their fate and her country's past. Ida's looking back at controversial events of the Second World War can be considered to be part of a debate that transcends Poland to involve the entirety of the European Union, and a reflection on a common past and on the ideals of remembrance and rejection of NaziFascism that we have already discussed.

From this perspective, $I d a$ is exemplary of a national cinema (for setting, story and language) with a transnational production background and an international reach, because of shared themes and the ability of art film to transcend borders.

The film seems aware of its derivation from a legacy of European art cinema and its language through the use of black-and-white cinematography, an out-of-fashion 4:3 framing and the lack of extradiegetic music. At the same time, in its "becoming minor", Ida borrows from established genres, such as the road movie and the coming-of-age drama, while addressing a very marginal character: the protagonist plans her definitive withdrawal from society after a life already spent in a monastery, with no knowledge of her family and her past. The pedagogical kit prepared by the Lux Prize touches in particular on the question on the artistic quality of the film, while stressing the presence of hard facts being told and the role played by the collective memory. It links the film to other productions inspired by the events of the Second World War and told through a personal story, while also underlining the "optimism" present in the film.

The issue of family and identity are again at the centre of Mustang, the Lux Prize winner of the following year. A German, Turkish, Qatari and French co-production, shot with the support of Eurimages, the Turkish Culture Ministry, the Filmförderungsanstalt (FFA), and the Centre National de la Cinématographie, alongside the participation of the Doha Film Institute, the film is entirely set in the north of Turkey and tells the story of five orphaned sisters living with their grandmother in a small village and facing the restrictions of a traditionalist patriarchal society. The film received theatrical distribution in 26 European Countries, it was screened at Cannes and was nominated for several awards, among which nine César (winning four) and two European Film Awards (wining one). Nevertheless, in respect to $I d a$, we can easily grasp the different international impact of the 
film, which reached fewer nations, and with the total number of admissions unsurprisingly dominated by the French box office (505.223 over 990,495), which mirrors the film's César success. In Germany (the other co-production nation and second market for number of admission with 128,339 tickets) the film was released only in 2016, after the award of the Lux Prize, whereas in Turkey Mustang reached a total of admissions of 24,419 spectators. Without wanting to speculate on these numbers, given that the French market counts for the majority of admissions not only for this film but also for several other Lux Prize winners, the Turkey box office of Mustang is revealing of the international vocation of art cinema and its struggles in the national context. Considering the aims and tools of the Lux Prize, it is noteworthy how the film performed abroad consistently better than in Turkey.

In Mustang the question of marginality is both thematic for the liminal characters, living at the edge of modernity and backwardness, and in its production context, with the regional settings in Turkey pushing the borders of the EU. The pedagogical kit strongly stresses the co-existing in the film of two conflicting sets of values (the new Civil Code for gender equality and the rise of conservative parties) mirroring the contrasts present in contemporary Turkey. However, it carefully points out that the one depicted is an "exceptional situation", while reminding that the position of women in society is "one of the criteria for accession to the European Europe". Interestingly, the kit then underlines the "fable-like" quality of the film, surprisingly dwelling on its comedy aspects.

A film selected to be representative of debates, values and identity in the European Union, Mustang does not feature one single location within the European Union borders or one single character with a nationality of one of the member states. Nevertheless, this co-production clearly engages with the outer edges of Europe, dealing with values of integration, diversity, gender equality, and the becoming of Europe.

In 2016 the Lux Prize was awarded to Toni Erdmann, a quadripartite co-production involving Germany, Austria, Romania and Switzerland. It received regional, national and supranational support from several initiatives, among which Eurimages, Filmstandort Austria, Filmstiftung Nordrhein-Westfalen (where the German shooting took place), Filmförderungsanstalt, and Medienboard Berlin-Brandenburg.

Albeit the data on European admissions are available for a shorter period of time compared to the other two case studies, and only comprised 19 European Countries at the moment of writing, the total admissions of 1.510 .732 placed Toni Erdmann as one of the most successful winners of the prize. It travelled to different film festivals like Toronto, London, and New York, was in competition for the Palme d'Or at Cannes and was nominated as best foreign language film at the 2017 Academy Awards. Different from the two previous winners, Toni Erdmann embraces in its 
storyline the transnational dimension of its production. The film prominently features three European languages (German, English and Romanian) and questions of dislocation through a story about a joke-prone father travelling to Bucharest to reconnect with his workaholic daughter. The latter works for a consultation company and moves to Bucharest to assess the possibility to restructure and outsource work in Romania. While the film plays with some comedy conventions and a plotline it shares with mainstream productions, its running time of 162 minutes, the lack of extradiegetic music, its realistic style and borderline situations refer to the tradition of European art film. The backdrop of the main storyline portrays the spectrum of the recent economic development in Romania: from the champagne-fuelled parties in Bucharest hotels to the poverty of its urban outskirts and countryside, the striking oppositions are constantly present. Questions of globalisation, international exploitation of workers and resources, cross-border movements, European interventions, and the greed of late capitalism, are all evident in the folds of the story about a father and daughter relationship. The pedagogical kit invites the viewer to reflect on the economic strategies emerging from the film and, more prominently, to consider the portrayed relationships between men and women as power relationships. The question of gender balance and dynamics are, once again, central in the kit alongside an analysis of the film's comedy elements and realism.

\section{Conclusions.}

Within a European Union framework, the Lux Prize works according to Vivien Schmidt's paradigm of political identity: being, doing and saying. It points out that European countries have common issues, values, and a shared past, which are understandable through cinema as privileged medium of cultural exchange. At the same time, it underlines that there are European institutions addressing the same issues, values and past, lending in this way visibility and a narrative to EU supranational policies.

Moreover, through its links and relationships with different European film festivals, the Lux Prize lets us know that there is a way to engage with those issues that is intrinsically European; the Prize in fact belongs to the cultural exception, and looks back to the legacy of art cinema.

Nevertheless, the "saying" of the Lux Prize works similarly to the top-down approach of the European Union. It points out a problem, informs us that said problem has been tackled through the work of a group of experts and employs a narrative centred on the question of identity and cultural belonging. However, this top-down approach cannot rely on sufficient financial resources to work properly, and the society does not seem to be involved in such process: there are no clear ways for 
the public to inform policies and actions, with the exclusion of a Twitter feed receiving little attention from the users.

Consequentially, the cinema promoted by the Lux Prize is the same cinema that manages to get institutional support for the production and for the construction of its cultural capital, in particular through film festivals, living in the shadow of the established modes and styles of the art film.

\section{References}

- Bayraktar, Nilgun. 2016. Mobility and Migration in Film and Moving Image Art: Cinema Beyond Europe. Abingdon: Routledge.

- Belfiore, Elenonora, Bennett, Oliver. 2008. "Introduction.” In The Social Impact of the Arts: An Intellectual History, edited by Elenonora Belfiore and Oliver Bennett, 1-12. Houndmills: Palgrave MacMillan.

- $\quad$ Bondebjerg, Ib, Novrup Redvall, Eva, Higson, Andrew. 2015. "Introduction.” In European Cinema and Television. Cultural Policy and Everyday Life, edited by Ib Bondebjerg, Eva Novrup Redvall and Andrew Higson, 1-22. Houndmills: Palgrave MacMillan.

- Czach, Liz. 2004. "Film Festivals, Programming, and the Building of a National Cinema." The Moving Image 4 (1): 76-88.

- $\quad$ De Valck, Marijke. 2016. "Fostering Art, Adding Value, Cultivating Taste: Film Festivals as Sites of Cultural Legitimization." In Film Festivals: History, Theory, Method, Practice, edited by Marijke De Valck, Brendan Kredell and Skadi Loist, 100-116. Abingdon: Routledge.

- $\quad$ Eder, Klaus. 2011. "Europe as a Narrative Network. Taking the Social Embeddedness of Identity Constructions Seriously." In Debating Political Identity and Legitimacy in the European Union, edited by Sonia Lucarelli, Furio Cerutti and Vivien A. Schmidt, 38-54. Abingdon: Routledge.

- $\quad$ English, James. 2008. The Economy of Prestige: Prizes, Awards, and the Circulation of Cultural Value. Cambridge MA: Harvard University Press. Kindle edition.

- $\quad$ Eurimages Strategy 2016-2017 for Gender Equality in the European Film Industry. 2016. Strasbourg: Council of Europe.

- $\quad$ European Parliament. 2014. 07-14 Lux Film Prize Catalogue. doi 10.2861/75006 
- European Union Agency for Fundamental Rights. 2013. The European Union as a Community of Values: Safeguarding Fundamental Rights in Times of Crisis. Luxembourg: Publications Office of the European Union.

- Galt, Rosalind, Schoonover, Karl. 2010. "Introduction. The Impurity of Art Cinema.” In Global Art Cinema: New Theories and Histories, edited by Rosalind Galt and Karl Schoonover, 3-27. New York: Oxford University Press.

- $\quad$ Iordanova, Dina. 2011. "East Asia and Film Festivals: Transnational Clusters for Creativity and Commerce." In Film Festivals Yearbook 3: Film Festivals and East Asia, edited by Dina Iordanova and Ruby Cheung, 1-37. St. Andrews: St. Andrews Film Studies.

- $\quad$ King, Geoff. "Defining Quality in Film.” Comunicazioni sociali XXXVII (3): 351-360.

- Jäckel, Anne. 2015. "Changing the Image of Europe? The Role of European co-Productions, Funds and Film Awards.” In The Europeanness of European Cinema: Identity, Meaning, Globalization, edited by Mary Harrod, Mariana Liz and Alissa Timoshkina, 59-71. London: I. B. Tauris.

- $\quad$ Katsarova, Ivana. 2014. “An Overview of Europe's Film Industry.” European Parliamentary Research Service. PE 545.705.

- $\quad$ Neale, Steve. 1981. “Art Cinema as an Institution.” Screen, 22 (1), 11-40.

- Rascaroli, Laura. 2013. "Becoming-minor in a sustainable Europe: the contemporary European art film and Aki Kaurismäki's Le Havre.” Screen 54 (3): 323-340

- $\quad$ Schmidt, Vivien. 2011. "The Problem of Identity and Legitimacy in the European Union. Is More Politics the Answer?" In Debating Political Identity and Legitimacy in the European Union, edited by Sonia Lucarelli, Furio Cerutti and Vivien A. Schmidt, 16-37. Abingdon: Routledge.

- Toggenburg, Gabriel N. 2003. "Cultural Diversity at the Background of the European Debate on Values - An Introduction.” In European Constitutional Values and Cultural Diversity, edited by Francesco Palermo and Gabriel N. Toggenburg, 9-23. Bozen-Bolzano: Europäische Akademie.

- $\quad$ Treaty of the European Union. 2012. Official Journal. C 326. 